\title{
Description of a new Indochinese Myotis (Mammalia: Chiroptera: Vespertilionidae), with additional data on the "M. annatessae" species complex
}

\author{
Sergey V. Kruskop*, Alex V. Borisenko, Anastasia V. Dudorova \\ \& Ilya V. Artyushin
}

\begin{abstract}
Based on the combination of cranial morphometry, morphology, DNA Barcoding data and one nuclear marker, the new species of Myotis is described from the Central Highlands of Vietnam and Laos. Externally resembling the recently described Myotis annatessae, it differs in a combination of external and craniometric characters and the sequence patterns of the DNA barcode region of COI and RAG2 nuclear gene. It is also markedly distinct from sympatrically co-occurring $M$. muricola and $M$. siligorensis, with which it may be confused in the field. Further data are provided on the M. "annatessae" species complex, including a putative range extension into West Bengal and a new geographic record for $M$. annatessae s. str. from North Vietnam.

How to cite this article: Kruskop S.V., Borisenko A.V., Dudorova A.V., Artyushin I.V. 2018. Description of a new Indochinese Myotis (Mammalia: Chiroptera: Vespertilionidae), with additional data on the " $M$. annatessae" species complex // Russian J. Theriol. Vol.17. No.1. P.17-31. doi: 10.15298/rusjtheriol. 17.1.02
\end{abstract}

KEY WORDS: Myotis, cryptic diversity, South-East Asia, Vietnam, DNA barcoding.

SergeyV. Kruskop [kruskop@zmmu.msu.ru ], Zoological Museum, Moscow State University, Bolshaya Nikitskaya, 2, Moscow 125009, Russia; Joint Vietnam-Russian Tropical Research and Technological Centre, Nguyen Van Huyen, Nghia Do, Cau Giay, Hanoi, Vietnam; AlexV. Borisenko [aborisen@uoguelph.ca], Centre for Biodiversity Genomics, Biodiversity Institute of Ontario, University of Guelph, Guelph, Ontario, Canada N1G 2W1; Anastasia V. Dudorova [fred0dy0n@gmail.com], IlyaV.Artyushin [sometyx@gmail.com],Dept.of Vertebrate zoology, Faculty of Biology, Moscow State University, Leninskiye Gory, 1, bld. 12, Moscow 119234, Russia.

\section{Описание нового вида рода Myotis (Mammalia: Chiroptera: Vespertilionidae) из Индокитая, с дополнительными данными по комплексу видов “M. annatessae"}

\section{С.В. Крускоп , А.В. Борисенко, А.В. Дудорова, И.В. Артюшин}

РЕЗЮМЕ. На основании данных краниометрии, морфологии и молекулярной генетики описывается новый вид ночниц Myotis из Центрального Нагорья Вьетнама и Лаоса. Весьма сходный с недавно описанной Myotis annatessae, новый таксон отличается сочетанием ряда внешних и краниометрических характеристик, а также последовательностями митохондриальной (вариабельный регион COI) и ядерной (RAG 2) ДНК. Он также надежно отличается от обитающих симпатрично $M$. muricola и M. siligorensis, с которыми может быть перепутан в полевых условиях. Приводятся дополнительные данные для всего видового комплекса $M$. “annatessae”, включая вероятное распространение на запад до Западной Бенгалии и новую географическую находку M. annatessae s. str. из Северного Вьетнама.

КЛЮЧЕВЫЕ СЛОВА: Myotis, скрытое разнообразие, Юго-Восточная Азия, Вьетнам, генный баркодинг.

\section{Introduction}

The chiropteran genus Myotis Kaup, 1829 ranks among the most speciose and widely distributed among mammals, with over 100 species worldwide (Simmons, 2005; Ruedi et al., 2013). The bulk of this diversity is

* Corresponding author concentrated in the Indo-Malayan Region, particularly, East Asia which is believed to be the centre of diversification of the genus (Ruedi et al., 2013) and where a number of recent revisions have been focussed (e.g., Csorba et al., 2014; Ruedi et al., 2015). The increasing use of molecular genetic markers helps to clarify divergence patterns obscured by morphological convergences (Ruedi \& Mayer, 2001) and to highlight potential 
undescribed diversity worthy of in-depth taxonomic scrutiny (Francis et al., 2010).

Within East Asia, Vietnamese bats have received considerable recent attention, both through intensified field surveys and taxonomic reassessments, which have boosted the country's faunal checklist by $20 \%$ over the past 15 years and ranking Vietnam among the top Old World nations in terms of bat diversity, at ca. 125 species (Kruskop, 2013a; Csorba et al., 2014; Son et al., 2015; Tu et al., 2015). The country remains a hotbed for new species descriptions, with many areas still poorly accessible to researchers and a highly complicated relief with mosaic ecozones (Kuznetsov, 2006), conducive to rapid phylogeographic diversification. $M y$ otis bats are a prime illustration of this, with a flurry of recently described new species (e.g., Csorba et al., 2011; Francis \& Eager, 2012; Thong et al., 2012; Kruskop \& Borisenko, 2013; Görföl et al., 2014; Son et al., 2015).

The discovery of deep mitochondrial divergences among lineages of Indochinese Myotis muricola-like bats (Francis et al., 2010) has prompted an in-depth taxonomic enquiry which later resulted in the description of one of these lineages from Central Vietnam and neighbouring parts of Laos as a new species, $M$. annatessae Kruskop et Borisenko, 2013. Initially confused with small M. muricola (Gray, 1846) (see Borissenko et al., 2001) or with $M$. siligorensis Horsfield, 1855 (see Borissenko \& Kruskop, 2003) on the basis of morphology, it was later found to possess distinguishing craniodental characteristics setting it aside from all other Myotis species (Kruskop \& Borisenko, 2013), which corroborated its deep divergence from $M$. muricola, based on the DNA barcode region of the cytochrome oxidase subunit 1 (COI) gene. Additional divergent nearest-neighbour COI haplogroups were observed on the COI tree which, although suggested to represent putative new species (Kruskop \& Borisenko, 2013), were not described at the time, due to insufficient data.

In 2015-2016, during field work executed by the Joint Vietnamese-Russian Tropical Research and Technological Centre in the Kon Tum Province of Vietnam, additional specimens have been collected, morphologically resembling $M$. annatessae. Furthermore, previously unstudied collection materials were analyzed, both morphologically and using DNA barcoding, which provided further insights into the structure of this species group and supported the description of an additional new species.

\section{Materials and methods}

Specimen collecting and processing. Seven specimens of Myotis used in this study were collected during the 2015-2016 field work in Kon Tum Province, Vietnam. Bats were captured in their flight paths and foraging areas with mist nets and flap traps (Kunz \& Kurta, 1990; Borissenko, 1999; Borissenko \& Kruskop, 2003). All captures took place between 1-6 hours following sunset. Individuals intended for vouchering were placed in cloth bags and euthanized in the vapours of chloroform, following protocols recommended by the American Society of Mammalogists Animal Care and Use Committee (Sikes et al., 2016).

Four external measurements (head and body, tail, ear and forearm length) were taken post-mortem with vernier callipers. Fixation in $75 \%$ ethanol followed within 10 to 15 minutes after euthanasia. Subsequent processing of collection material resumed within several months following fixation. External measurements were taken with vernier or electronic callipers to the nearest $0.1 \mathrm{~mm}$. Skulls of collected specimens were extracted and cleared in a dermestarium. Cleaned skulls were measured under a dissecting microscope with electronic callipers to the nearest $0.01 \mathrm{~mm}$. Tissue samples for DNA extraction were taken from pectoral muscle of freshly sacrificed specimens.

Comparative material. A total of 188 specimens of small South-East and Central Asian "whiskered bats" (Myotis muricola s. lato, M. annatessae s. lato, $M$. davidii $^{1}$ Peters, 1869), including putative new species, were exampled and used in morphometric analyses. Acronyms of repositories of the processed collections are as follows: BMNH - Natural History Museum, London; HNHM - Hungarian Natural History Museum, Budapest; MNHN — National Museum of Natural History, Paris; NMP — Natural History division of the National Museum, Prague; NMW - Vienna Museum of Natural History; ROM - Royal Ontario Museum, Toronto; ZCU — Charles University, Prague; ZIN — Zoological Institute, Russian Academy of Sciences, St. Petersburg; ZMB - Museum für Naturkunde Berlin (Zoological Collections) Berlin Zoological Museum, Berlin; ZMMU - Zoological Museum of Moscow State University, Moscow. Full list of these specimens is provided in the Appendix 1.

Additionally, 99 specimens of the following Myotine species from different parts of South, Central and South-East Asia were used for qualitative comparison: Myotis ater Peters, 1866 (including cotype of $M$. ater ZMB 2956, and type of $M$ amboinensis (Peters, 1871) ZMB 3119), M. siligorensis (including type BMNH 79.11.21.125), Submyotodon caliginosus Tomes, 1859 (including four cotypes of "Myotis" blanfordi (Dobson, 1871) BMNH75.10.27.1-2, ZMB 4373, ZMB 4117) and S. moupinensis (Milne-Edwards, 1872) (including two paratypes MNHN1870-589). These specimens were excluded from statistical analyses, either because they were clearly distinguishable using qualitative traits alone or because there was considerable hiatus (no overlap) in select cranial measurements.

A total of 142 specimens representing 11 Asian Myotis species were analyzed for patterns of genetic divergence in the COI region. Molecular data were taken from published online projects housed by the

${ }^{1}$ The so-called 'steppe whiskered bat' was formerly known as M. aurascens Kuzyakin, 1935; we apply the name "davidii Peters, 1869", following the suggestion of Benda et al. (2012), corroborated by our own study of the " $V$. davidii" holotype (SVK, unpublished). 
Barcode of Life Data Systems (BOLD; www. boldsystems.org) and aggregated into the dataset [DSMANCSPN] "Myotis ancricola sp.n. - COI sequence comparison". A list of BOLD Process ID numbers is also provided in Appendix 2.

Original sequences of RAG2 nuclear gene were obtained for 17 specimens from ZMMU collection, including five individuals of the new putative species (GenBank No's MN328025-328041). Also, five previously published sequences (Ruedi et al., 2013; KF312551.1, KF312552.1, KF312553.1, KF312559.1, AM265678) were used in this analysis.

Morphometric analyses. The following external measurements were taken from fluid-preserved carcasses or dry skins: forearm length, tibia length, foot length (including claws, measured to the distal extremity of claw), length of the first digit (including claw), length of the metacarpal of the second digit, and lengths of the metacarpals and phalanges of the third, through and fifth digits. All wing measurements were taken on the right wing, unless unsuitable (e.g., damaged) or inaccessible for measuring. The following cranial measurements (abbreviations given in parentheses), were taken: condylobasal length (CBL), condylocanine length (CCL), brain case height posterior to auditory bullae $(\mathrm{BCH})$, mastoid width of skull at the level of the auditory bullae (MW), width of braincase (BCW), least width of the postorbital constriction (POW), rostral width at the level of the infraorbital foramina (RW), rostral length from anteorbital foramen to the alveolus of the inner incisor (RL), C-M3 length (CM3), maxillary molariform row length (P4M3), length of the upper canine cingulum base $(\mathrm{C})$, length of interval between cingula of upper canine and large premolar ("pseudodiastem", Pseud), crown-measured width between the outer margins of upper canines (CC), crown-measured width between outer margins of M3 (M3M3), crown width of M2 (M2), lower jaw length from alveolus of i1 to the posterior extremity of glenoid process $(\mathrm{MdLg})$, lower jaw length from alveolus of il to the posterior extremity of angular process (MdLa), crown length of mandibular tooth row $(\mathrm{cm} 3)$, crown length of mandibular molariform row (p4m3), lower jaw height to the tip of coronoid process $(\mathrm{MdH})$.

To assess the pattern of variation of quantitative characters, Principal Component (PC) and Discriminant Analyses were performed for the 20 craniodental measurements, using the Discriminant Function and Principal Component Analysis and Classification modules of STATISTICA for Windows version 7.0 (StatSoft, Inc., 2004). DF analysis was used to calculate Squared Mahalanobis Distances between groups and significance of inter-group difference. The training set for calculating Squared Mahalanobis Distances for the Discriminant Analysis included nine samples: four geographically separated samples of $M$. muricola form Indochina, Malaysia, Great Sunda Islands and India/ Nepal; and one sample of each from $M$. davidii, $M$. annatessae s. str., $M$. cf. annatessae from China, $M$. cf. annatessae from West Bengal, and the putative new species.

Molecular analyses. Analysis of the standard DNA barcode region (657 base pair 5' segment of the mitochondrial cytochrome oxidase subunit I (COI)) was performed by the staff of the Centre for Biodiversity Genomics (CBG), University of Guelph, Canada. The gene was sequenced bidirectionally using standard DNA barcoding protocols for mammals (Ivanova et al., 2012). Whole genomic DNA from ethanol-preserved tissue was recovered using an automated DNA extraction method. PCR amplification for the standard DNA barcode region was done using M13-tailed primer cocktails C_VF1LFt1 and C_VR1LRt1. PCR products were sequenced using an ABI Prism BigDye Terminator $\mathrm{V}$ 3.1. Cycle Sequencing kit and analyzed on ABI 3730XL Genetic Analyzer. Sequences were assembled and manually edited in CodonCode Aligner 3.7.1 software (CodonCode Corporation) by CCDB sequencing technicians.

Analysis of molecular COI data was performed using MEGA ver. 5 molecular genetic analysis software (Tamura et al., 2011). A distance-based tree with 142 specimens was built with the Neighbour-Joining algorithm using the Kimura-2-parametr model (Tamura et al., 2007) and pairwise deletion of missing data. Branch support was assessed by bootstrapping with 1000 replicates.

For sequencing RAG2 nuclear gene DNA was extracted by phenol-chloroform deproteinization, and gene fragment was sequenced with custom primers RAG2f63ept (GATTCCTGCTACCTTCCTCCTCTTC) and RAG2-r1122ept (GAGCAGCATGTAATCC-AGTAGCCAGT). Amplification included initial denaturation at $94^{\circ} \mathrm{C}$ for $3 \mathrm{~min}$, and 35 cycles with further conditions: denaturation at $94{ }^{\circ} \mathrm{C}$ for $30 \mathrm{~s}$, annealing at $60^{\circ} \mathrm{C}$ for $1 \mathrm{~min}$, and extension at $72^{\circ} \mathrm{C}$ for $1 \mathrm{~min}$, followed by a final extension at $72^{\circ} \mathrm{C}$ for $6 \mathrm{~min}$. Sequencing was performed by the "Eurogen" company (Moscow, Russia).

We aligned sequences with ClustalW with further manual inspection and correction. Final matrix included 22 sequences up to $868 \mathrm{bp}$. For the data partitioning scheme and evolution model selection PartitionFinder v1.1.1 was used (Lanfear et al., 2012). Partitioning scheme was selected as follows: $1 \mathrm{st}+2$ nd positions with HKY model versus 3rd position with K80 model. Bayesian analysis was performed in mrBayes v3.2.6 (Ronquist \& Huelsenbeck, 2003). Convergence was assessed using RWTY (Warren et al., 2017) for R ver. 3.4.3 (Bates et al., 2017). Genetic K2P-distances were calculated in MEGA 7 (Kumar et al., 2016).

\section{Results and discussion}

Patterns of variation in the DNA markers. All specimens morphologically conforming to the " $M$. annatessae" species complex form a well-supported (Bootstrap index of 99) cluster of COI DNA barcode haplo- 


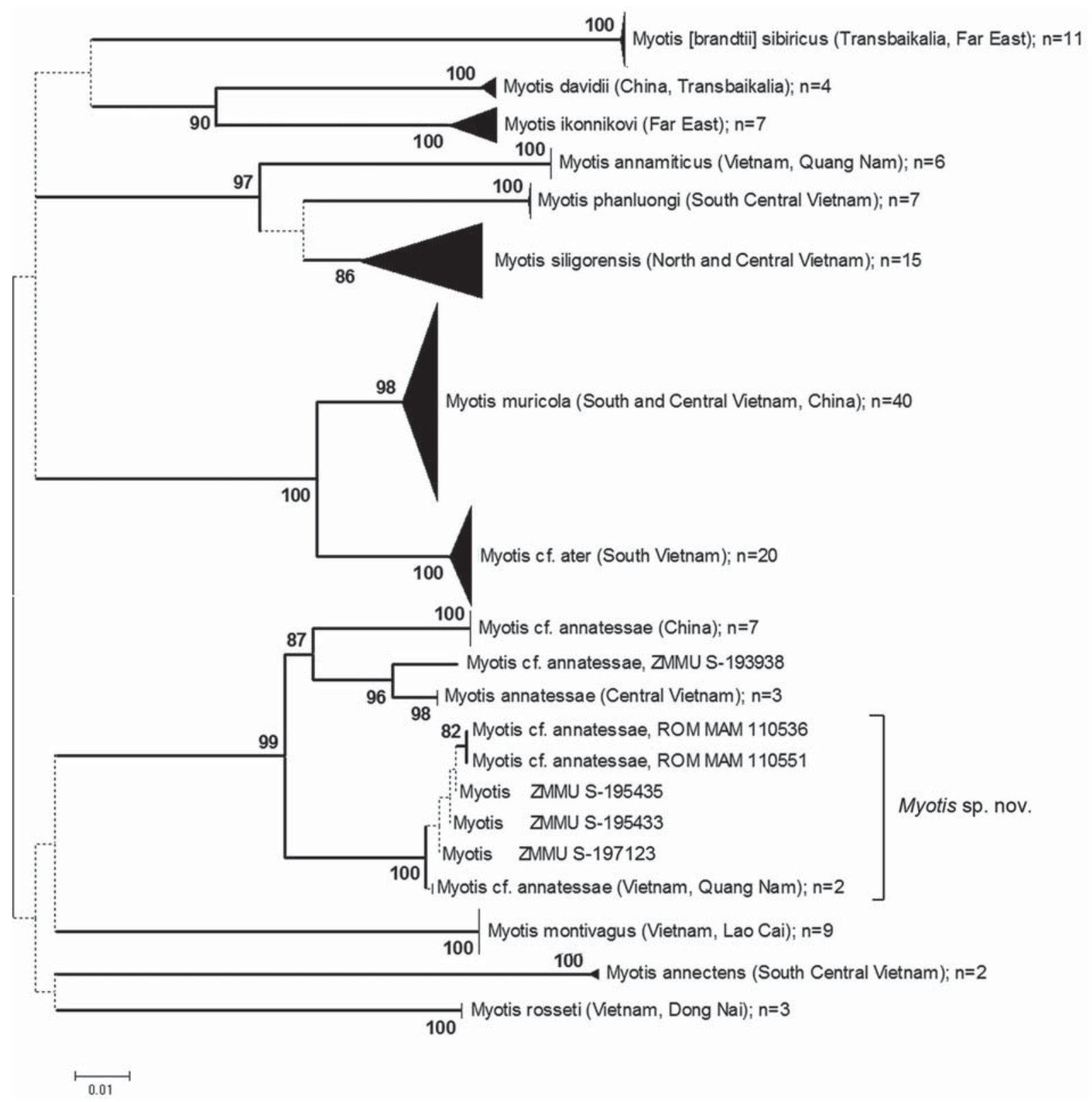

Fig. 1. Kimura-2-parameter tree for COI mt-gene sequences of 11 Asian mouse-eared bats. Only bootstrap supports over 70 are shown.

groups (Fig. 1). Although insufficient to infer phylogenetic relationships, these results indicate a high level of divergence between " $M$. annatessae" and "M. murico$l a$ " species complexes. Within the "M. annatessae" grouping, three ZMMU specimens from Kon Tum (Vietnam), two ROM specimens from neighboring Quang Nam (Vietnam) and another two ROM specimens from Attapu (Laos) form a compact haplogroup with intragroup diversity of ca. $0.3 \%$. Pairwise distances from the nearest neighbors ( $M$. annatessae s. str. and Chinese $M$. cf. annatessae) are 5.6 and $6.9 \%$, respectively; which is similar to the mean interspecific distance, calculated for COI of Asian species of Myotis (Francis et al., 2010).

Similarly to COI data, all specimens associated to the " $M$. annatessae" species complex form a highly supported cluster of RAG2 sequences (Fig. 2). Within this cluster, five individuals representing newly describing species take a sister position for three GenBank specimens, one of which (KF312553) was identified as M. annatessae by Barcoding data (BM213-03), and another one (KF312552) was included into our morphometric analysis as $M$. cf. annatessae (NMP 90553) from China. Mean distance of Kon Tum speci- 


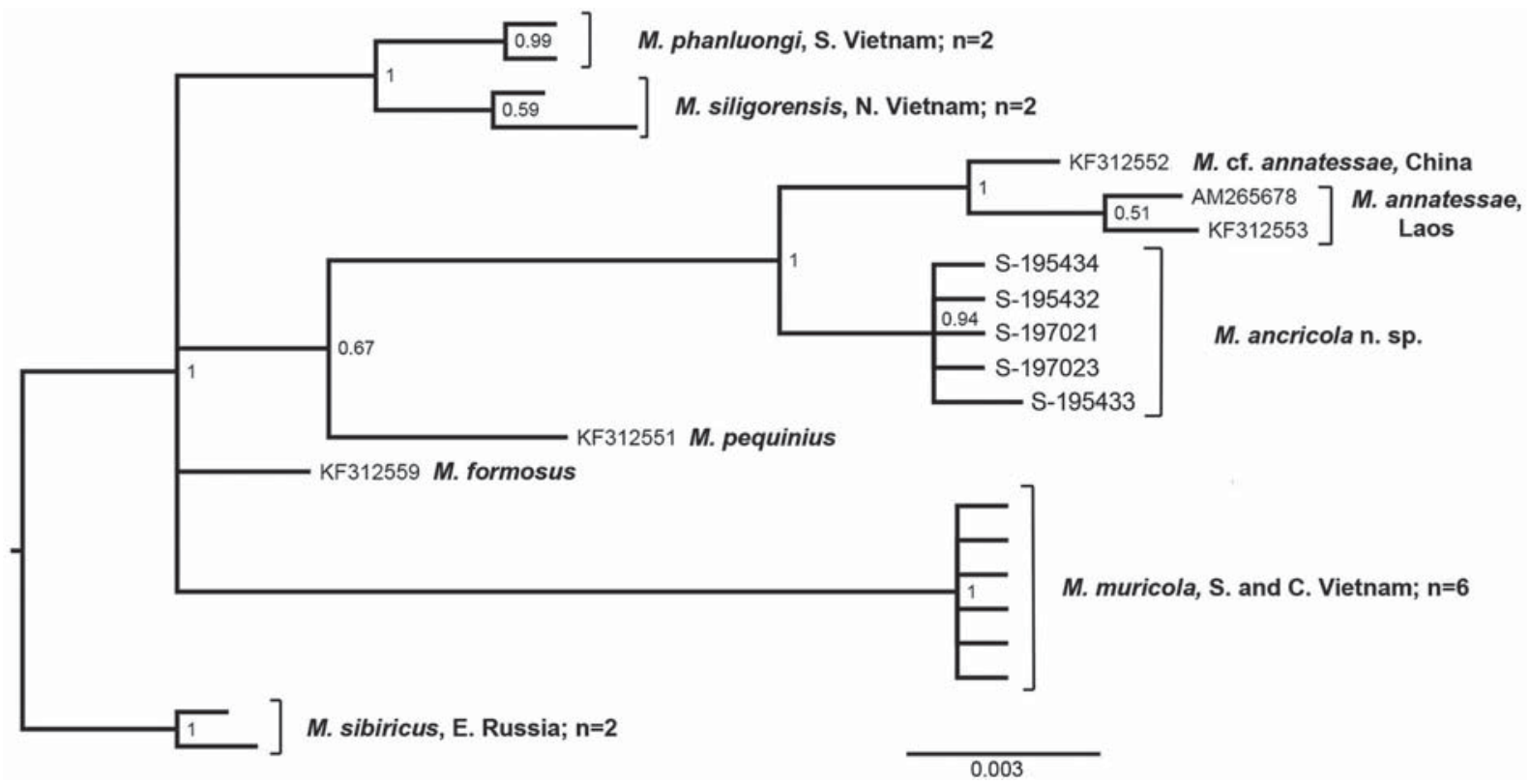

Fig. 2. Baesian tree for RAG2 nu-gene sequences of selected Asian mouse-eared bats.

mens from those tree is about $0.4 \%$, which is ca. twice larger than the distance between $M$. phanluongi and $M$. siligorensis and corresponds to distances between related Myotis species as shown by Ruedi et al. (2013, suppl.). The whole "annatessae" clade is well-separated from M. muricola; distances of M. muricola from $M$. annatessae and from Kon Tum specimens are 1.6 and $1.9 \%$, respectively.

This genetic divergence pattern is in agreement with observed cranial differences and suggests that the sample of the specimens from the Vietnamese Central Highlands and adjacent Laos represent a separate unnamed species which is described below.

Variation of cranio-dental morphometry. All the "whiskered bats" are quite similar in their morphology and could be misidentified in the field. However, earlier analyses (Kruskop \& Borisenko, 2013) have outlined significant cranial and dental differences between $M$. annatessae and other species of East Asian "whiskered bats" which may be confused morphologically. That includes proportionally small canines (especially lower, which height not exceed that of appropriate large premolars) and small overall skull size in combination with clearly myotodont lower molars and not abruptly concaved frontal skull profile. Additional material on small Southeast Asian Myotis analyzed here, conforms to these earlier findings.

A small series of six BMNH specimens from "Hasimara, Bhutan" (currently, West Bengal, India) originally identified as $M$. muricola and later referred to as $M$. nipalensis (see: Benda, 2010) demonstrates strong morphometric similarity to the " $M$. annatessae" complex, which is corroborated by the qualitative cranio-dental characters, mentioned above, and pelage coloration sim- ilar to that of $M$. annatessae and putative new species (see below). Therefore, we provisionally identify it as $M$. cf. annatessae, pending molecular genetic data or additional materials.

A bivariate scatterplot of the first two Principal Components, calculated using 20 cranio-dental measurements (Fig. 3, Tab. 1), demonstrates noticeable segregation between $M$. muricola s.l. and the " $M$. annatessae" species complex and a slight overlap between the latter and $M$. davidii.

A separate analysis performed for the "annatessae" species complex (Fig. 4) shows less segregation but maintains a pattern consistent with putative taxonomic or phylogeographic groupings.

Squared Mahalanobis distances calculated for the entire morphometric dataset (Tab. 2) demonstrate marked distinction between group centroids of " $M$. muricola" and "M. annatessae" species complexes, and also between both of them and $M$. davidii.

A separate Discriminant Function Analyses restricted to 36 measured specimens of the annatessae complex (Fig. 5) demonstrated separation between M. annatessae s. str., M. ancricola, sp. n., and the specimens from China, but failed to discriminate between M. ancricola, sp. n. and the series from West Bengal.

Baculum shape. Baculum is considered to be an informative diagnostic feature in vespertilionids (Hill \& Harrison, 1987; Horáček \& Hanák, 1986), including Myotis (Strelkov, 1989; Benda \& Tsytsulina, 2000; Kruskop, 2013b). Penial bones extracted from two specimens from Vietnam Central Highlands are different in details from those of $M$. annatessae s. str. and $M$. muricola (Fig. 6), as well as M. ater, M. davidii and $M$. siligorensis s.lato. 


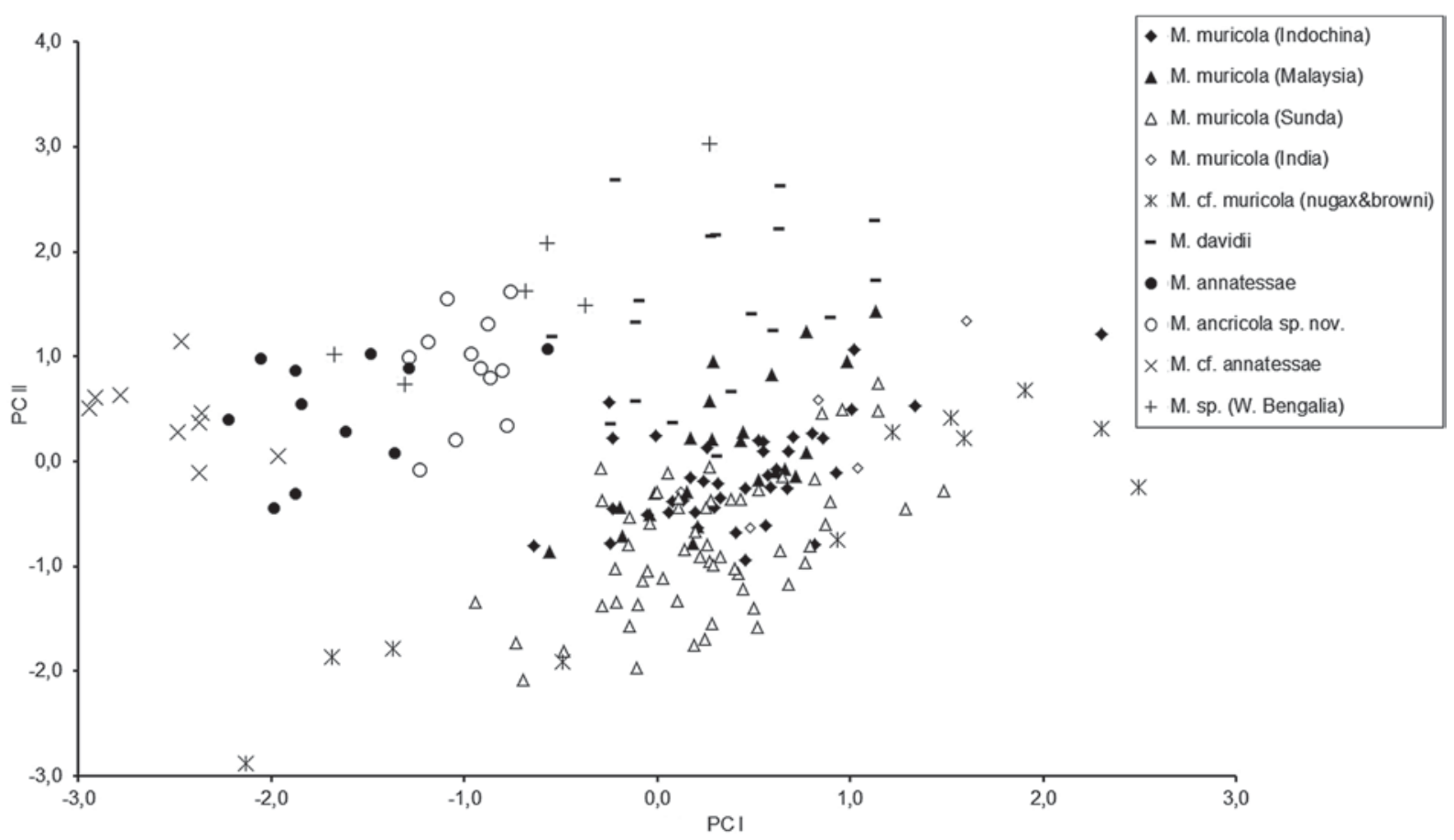

Fig. 3. Bivariate scatter plot for the two first Principal Components, calculated for 19 cranial and dental measurements of 193 specimens of smaller Asiatic mouse-eared bats. For factor loadings and Eigenvalues see Table 1.

Table 1. Factor loadings and Eigenvalues for the first four factors of the Principal Component analysis.

\begin{tabular}{|l|c|c|c|c|}
\hline & Factor 1 & Factor 2 & Factor 3 & Factor 4 \\
\hline CBL & $\mathbf{0 , 8 5 1}$ & 0,230 & 0,161 & 0,060 \\
\hline CCL & $\mathbf{0 , 8 5 1}$ & 0,160 & 0,195 & 0,137 \\
\hline BCH & 0,164 & 0,215 & 0,121 & 0,150 \\
\hline MW & 0,528 & 0,446 & 0,071 & 0,116 \\
\hline BCW & 0,016 & $\mathbf{0 , 9 2 3}$ & 0,012 & $-0,054$ \\
\hline POW & $-0,100$ & $\mathbf{0 , 8 4 2}$ & $-0,149$ & 0,316 \\
\hline RW & 0,333 & 0,266 & 0,116 & 0,771 \\
\hline RL & $\mathbf{0 , 8 4 0}$ & 0,179 & 0,052 & $-0,119$ \\
\hline CM3 & $\mathbf{0 , 9 3 4}$ & $-0,036$ & 0,097 & 0,183 \\
\hline P4M3 & $\mathbf{0 , 9 2 8}$ & $-0,008$ & $-0,178$ & 0,156 \\
\hline C & $\mathbf{0 , 8 2 0}$ & $-0,020$ & $-0,335$ & 0,187 \\
\hline PD & $-0,049$ & $-0,097$ & $\mathbf{0 , 9 6 0}$ & 0,059 \\
\hline CC & 0,637 & 0,215 & $-0,019$ & 0,467 \\
\hline M3M3 & 0,539 & 0,066 & $-0,076$ & 0,373 \\
\hline WM2 & $\mathbf{0 , 8 0 3}$ & $-0,179$ & $-0,198$ & 0,269 \\
\hline MDLG & $\mathbf{0 , 8 8 2}$ & $-0,025$ & 0,157 & 0,195 \\
\hline CM3 & $\mathbf{0 , 9 4 9}$ & $-0,013$ & 0,038 & 0,147 \\
\hline P4M3 & $\mathbf{0 , 9 1 3}$ & 0,054 & $-0,170$ & 0,099 \\
\hline MDH & 0,791 & $-0,227$ & $-0,021$ & 0,230 \\
\hline Eigenvalue & 11,131 & 2,560 & 1,435 & 0,862 \\
\hline \% Total Var. & 58,587 & 13,472 & 7,551 & 4,539 \\
\hline Cumul. Eig. & 11,131 & 13,691 & 15,126 & 15,988 \\
\hline Cumul. \% & 58,587 & 72,059 & 79,610 & 84,149 \\
\hline
\end{tabular}




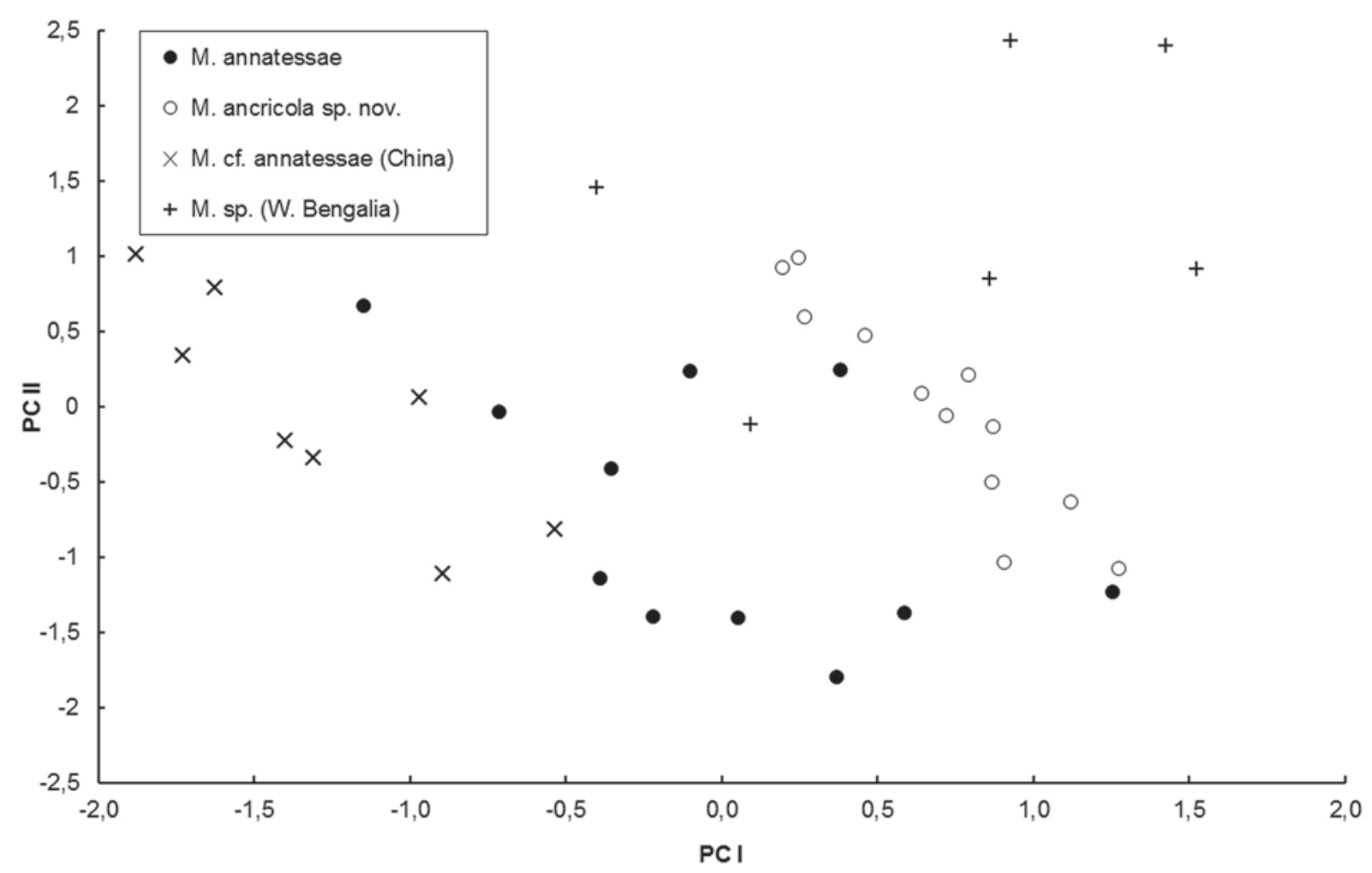

Fig. 4. Bivariate scatter plot for the two first Principal Components, calculated for 19 cranial and dental measurements of 38 specimens of the Myotis «annatessae» complex. First PC (Eigenvalue 12.9858 ; \% of total variance 68.3465) mainly correlates with overall size; second one (Eigenvalue 1.31816; \% of total variance 6.93766) has major correlations with POC, BCW and MW.

Table 2. Significance of intergroup difference and Squared Mahalanobis distances between groups of small Asian Myotis.

\begin{tabular}{|l|r|r|r|r|r|r|r|r|c|}
\hline & 1 & 2 & 3 & 4 & 5 & 6 & 7 & 8 & 9 \\
\hline 1 M. muricola (Indochina) & & 0,0000 & 0,0000 & 0,0011 & 0,0000 & 0,0000 & 0,0000 & 0,0000 & 0,0000 \\
\hline 2 M. muricola (Malaysia) & 5,169 & & 0,0000 & 0,0019 & 0,0000 & 0,0000 & 0,0000 & 0,0000 & 0,0000 \\
\hline 3 M. muricola (Great Sunda Islands) & 3,823 & 8,339 & & 0,0000 & 0,0000 & 0,0000 & 0,0000 & 0,0000 & 0,0000 \\
\hline 4 M. muricola (India/Nepal) & 12,260 & 12,435 & 14,604 & & 0,0000 & 0,0000 & 0,0000 & 0,0000 & 0,0000 \\
\hline 5 M. annatessae s. str. & 53,379 & 65,788 & 59,922 & 75,887 & & 0,0280 & 0,0001 & 0,0000 & 0,0000 \\
\hline 6 M. ancricola sp. n. & 31,285 & 39,319 & 37,330 & 51,525 & 6,684 & & 0,0000 & 0,1069 & 0,0000 \\
\hline 7 M. cf. annatessae (China) & 85,370 & 95,367 & 93,887 & 114,837 & 12,696 & 21,563 & & 0,0000 & 0,0000 \\
\hline 8 M. cf. annatessae (W. Bengal) & 37,776 & 39,091 & 44,798 & 47,689 & 18,319 & 7,811 & 37,739 & & 0,0000 \\
\hline 9 M. davidii & 40,527 & 49,130 & 52,586 & 45,435 & 55,660 & 45,794 & 75,620 & 54,608 & \\
\hline
\end{tabular}

\section{Systematic part}

Order Chiroptera Blumenbach, 1779

Family Vespertilionidae Gray, 1821

Subfamily Myotinae Tate, 1942 Genus Myotis Kaup, 1829

\section{Myotis ancricola sp.n.}

Holotype. ZMMU S-195433 (alcohol-preserved, skull and baculum extracted), adult male; Vietnam,
Kon Tum Province, Kon Plong district, $14 \mathrm{~km} \mathrm{NNE}$ from town Mãng Đen, Thak Nam forestry; N 14²43.3' E 108¹8.9', elevation 1040 m A.S.L.; 19.04.2015; coll. Sergey V. Kruskop.

Paratypes. Five adult males, ZMMU S-195432, 195435 (alcohol-preserved), S-195434 (alcohol-preserved, skull extracted, without mandible), 1523.04.2015; ZMMU S-197021, 197023, (alcohol-preserved, skulls extracted), 5-10.06.2016; same locality and collector as in holotype. 


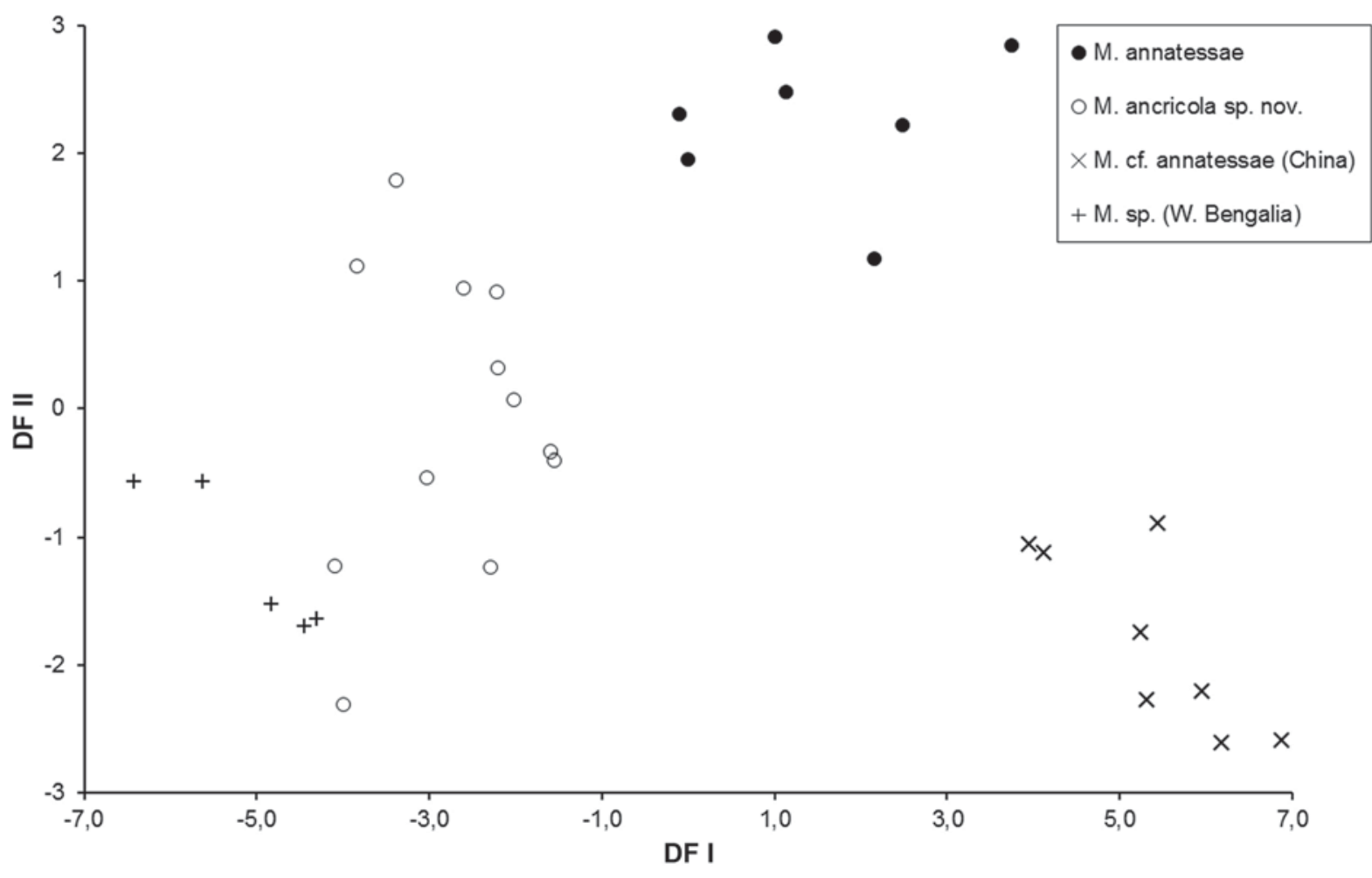

Fig. 5. Bivariate scatter plot for the two first canonical scores (Discriminant Function analysis), calculated for 19 cranial and dental measurements of 38 specimens of the Myotis «annatessae» complex.

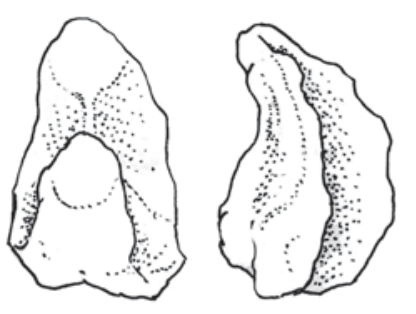

a

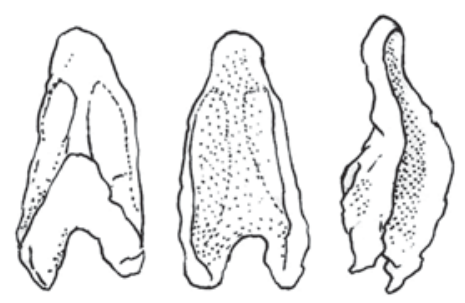

d

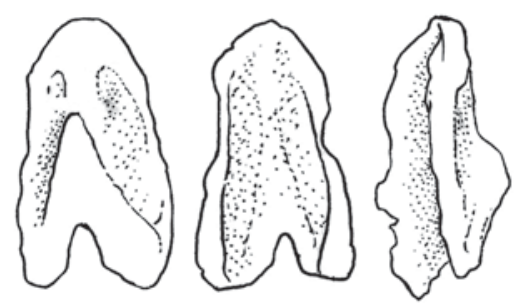

b
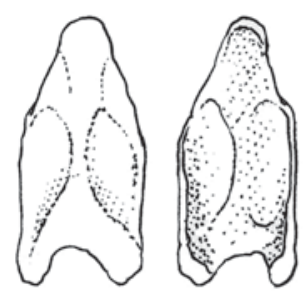

e
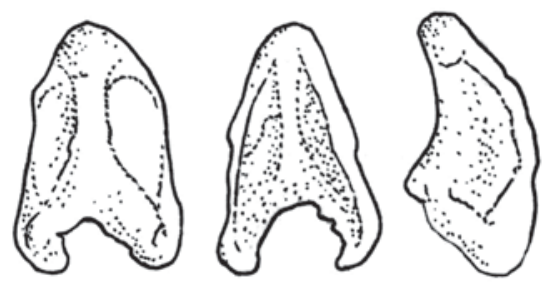

C

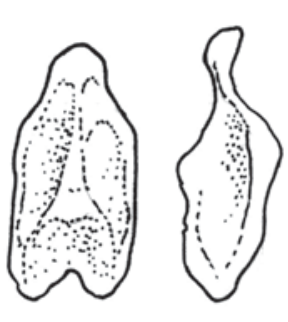

$\mathbf{f}$

Fig. 6. Camera Lucida traces of penial bones (bacula) in new Myotis species in comparison to M. annatessae and M. muricola: a, b - M. ancricola sp. n., Vietnam, ZMMU S-195433 (holotype; dorsal, right lateral views), ZMMU S-195434 (dorsal, ventral, left lateral views); c - M. annatessae, Vietnam, ZMMU S-164989 (dorsal, ventral, right lateral views); d, e, f - M. muricola, Vietnam, ZMMU S-195429 (dorsal, ventral, right lateral views), ZMMU S-195431 (dorsal, ventral, leftt lateral views), ZMMU S-172616 (dorsal, right lateral views. Scale bar $=1 \mathrm{~mm}$. 
Other referenced material. Eight specimens from Vietnam (Ngoc Linh) and Laos in ROM collection: see in the Appendix 1 as M. ancricola sp.n.

Type locality. Thak Nam forestry, Kon Plong district, Kon Tum Province, Vietnam.

Diagnosis. Small bat of "whiskered-bat" morphotype, very similar in external and cranio-dental traits $M$. annatessae and superficially resembling sympatrically co-occurring $M$. muricola and $M$. siligorensis, and also some extralimital species like $M$. mystacinus. Differs from M. annatessae in darker coloration, longer tail, craniometrically, genetically, and in known distribution range. Differs $M$. muricola by smaller overall size, skull and dentition and absence of calcar lobe; from $M$. siligorensis by somewhat larger size, broader ears with shorter tragi, larger canines, less concave frontal profile of the skull and myotodont lower molars. Baculum is similar to that of $M$. annatessae in general shape, but differing in minor details (Fig. 6).

DNA barcode of the holotype. BOLD (www. boldsystems.org) dataset [DS-MANCSPN] "Myotis ancricola sp. nov. - COI sequence comparison", Process ID SKZMR015-16.

Measurements of the holotype. External measurements: head \& body $=38 \mathrm{~mm}$; tail $=37 \mathrm{~mm}$; forearm $=$ $34.3 \mathrm{~mm}$; hind foot $=6.2 \mathrm{~mm}$; tibia $=14.5 \mathrm{~mm}$; thumb (without claw) $=5.3 \mathrm{~mm}$; ear pinna $=13.2 \mathrm{~mm}$; wing span $=230.0 \mathrm{~mm}$. Skull measurements: $\mathrm{CBL}=12.37$ $\mathrm{mm} ; \mathrm{CCL}=11.53 \mathrm{~mm} ; \mathrm{BCH}=5,22 \mathrm{~mm} ; \mathrm{MW}=6.98$ $\mathrm{mm} ; \mathrm{BCW}=6.78 \mathrm{~mm} ; \mathrm{IOW}=3.42 \mathrm{~mm} ; \mathrm{RW}=3.52$ $\mathrm{mm} ; \mathrm{RL}=2.70 \mathrm{~mm} ; \mathrm{CM} 3=4.80 \mathrm{~mm} ; \mathrm{P} 4 \mathrm{M} 3=3.52$ $\mathrm{mm} ; \mathrm{C}=0.62 \mathrm{~mm}$; Pseud $=0.61 \mathrm{~mm} ; \mathrm{CC}=3.41 \mathrm{~mm}$; $\mathrm{M} 3 \mathrm{M} 3=5.24 \mathrm{~mm} ; \mathrm{M} 2=1.25 \mathrm{~mm} ; \mathrm{MdLg}=9.35 \mathrm{~mm}$ $\mathrm{MdLa}=9.57 \mathrm{~mm} ; \mathrm{cm} 3=5.09 \mathrm{~mm} ; \mathrm{p} 4 \mathrm{~m} 3=3.72 \mathrm{~mm}$ $\mathrm{MdH}=2.38 \mathrm{~mm}$.

Etymology. The species epithet is derived from Latin 'ancra' — 'gorge, valley' and 'colo' — 'to inhabit, to cultivate', and refers to the type of habitat where bats have been collected.

Description and comparison. Small-sized Myotis (FA ca. 31.8-34.1 mm, BM ca. 3.7-4.7 g) of "whiskered-bat" appearance, very closely resembling $M$. annatessae. Tail shorter than head and body by about 7-8 $\mathrm{mm}$. Fur moderately thick; dorsal hairs about 5-6 mm in length; ventral hairs 4-5 $\mathrm{mm}$, extending onto the wing membranes and tail membrane by about $4 \mathrm{~mm}$. Pelage coloration relatively dark, greyish-brown to blackish-brown; somewhat darker, compared to M. annatessae. Blackish or dark-brown coloration of individual dorsal hairs spreads up to two thirds of the hair length, and only distal third of the hair is paler brown or grayish-brown. In some specimens, guard hairs are tipped with silvery-white, forming a very subtle mottled pattern on the dorsal side. Dark coloration expands also onto throat and sides; only mid-ventral part is noticeably paler, where hairs possess distinct silvery-whitish tips, similar to $M$. annatessae, although in the latter species the tips are shorter and brown rings below them are less pronounced. Ventral coloration is uniform from the lower throat to the groin area. Hairless parts of skin mostly dark-brown; although external genitalia lack dark pigmentation. Muzzle covered with dark hairs up to nostrils; hairs sparser below eyes and on upper lip. Ears moderately long, barely reaching the tip of muzzle if laid forward, bluntly pointed at tips, with weak posterior emargination. Tragus just below $1 / 2$ of ear pinna in height, bluntly pointed, slightly curved forward at tip. Wings moderately long, with third metacarpal about 2 $\mathrm{mm}$ longer than fourth. Thumb about 5.2-5.9 $\mathrm{mm}$ in length, its claw is sharply pointed but in general looks shorter and less sharp than in M. annatessae. Hind foot measured without claws about $39 \%$ of tibia length, proportionally shorter than in $M$. annatessae, on average. Calcar lobe lacking. Wing membrane attaches to the base of the proximal phalanx of outer finger. Penis proportionally thick, compared to $M$. annatessae, rather resembling that of subadult $M$. brandtii; somewhat bulbous and widened in its distal half.

Table 3. Significance of intergroup difference and Squared Mahalanobis distances between groups in analysis reduced to the Myotis "annatessae" complex.

\begin{tabular}{|l|c|c|c|c|}
\hline & 1 & 2 & 3 & 4 \\
\hline $\begin{array}{l}1 \text { M. annatessae } \\
\text { s. str. }\end{array}$ & 6,749 & 0,000 & 0,000 & 0,000 \\
\hline $\begin{array}{l}2 \text { M. ancricola } \\
\text { sp. } \text {. }\end{array}$ & 13,237 & 23,648 & 0,000 & 0,012 \\
\hline $\begin{array}{l}3 \text { M. cf. annatessae } \\
\text { (China) }\end{array}$ & 11,793 & 3,297 & 26,982 & 0 \\
\hline $\begin{array}{l}4 M \text {. cf. annatessae } \\
\text { (W. Bengal) }\end{array}$ & & \\
\hline
\end{tabular}

Skull small, $($ mean CCL $=11.93 \pm 0.1 \mathrm{~mm}$; CM3 = $4.98 \pm 0.05 \mathrm{~mm}$ ), larger on average than in $M$. annatessae (mean CCL $=11.6 \mathrm{~mm}$; CM3 $=4.79 \mathrm{~mm}$ ), but smaller than in $M$. muricola (mean $\mathrm{CCL}=12.25 \mathrm{~mm}$; CM3 $=5.25 \mathrm{~mm}$ ). For full set of skull measurements see Tab. 3. Skull shape nearly identical to that of $M$. annatessae and typical of small Myotis, with low and narrow rostrum, bulbous braincase and concave frontal profile. These features are more pronounced, compared to $M$. muricola, but less so, compared to the " $M$. siligorensis" complex (Figs 7, 8). In lateral view, the highest points of frontal and occipital areas are approximately on the same level, compared to M. muricola where the occipital portion is higher. Sagittal crest reduced; lambdoid crests visible, their shape usually more straight than in $M$. annatessae; occipital crest absent. Zygomatic arch is slender than in M. muricola, but much wider than in M. siligorensis; in comparison to M. annates$s a e$, its anterior root situated higher from the molar alveoli. Anterorbital opening is situated over posterior root of $\mathrm{P} 4$ or over gap between it and first root of $\mathrm{M} 1$; maxillary channel moderately short. Posterior palatal emargination is rectangular in shape. Basicranial pits are well-developed. Anterior edge of coronoid process almost vertical; angular process somewhat longer than articular, its distal end slightly curved upward. Coro- 

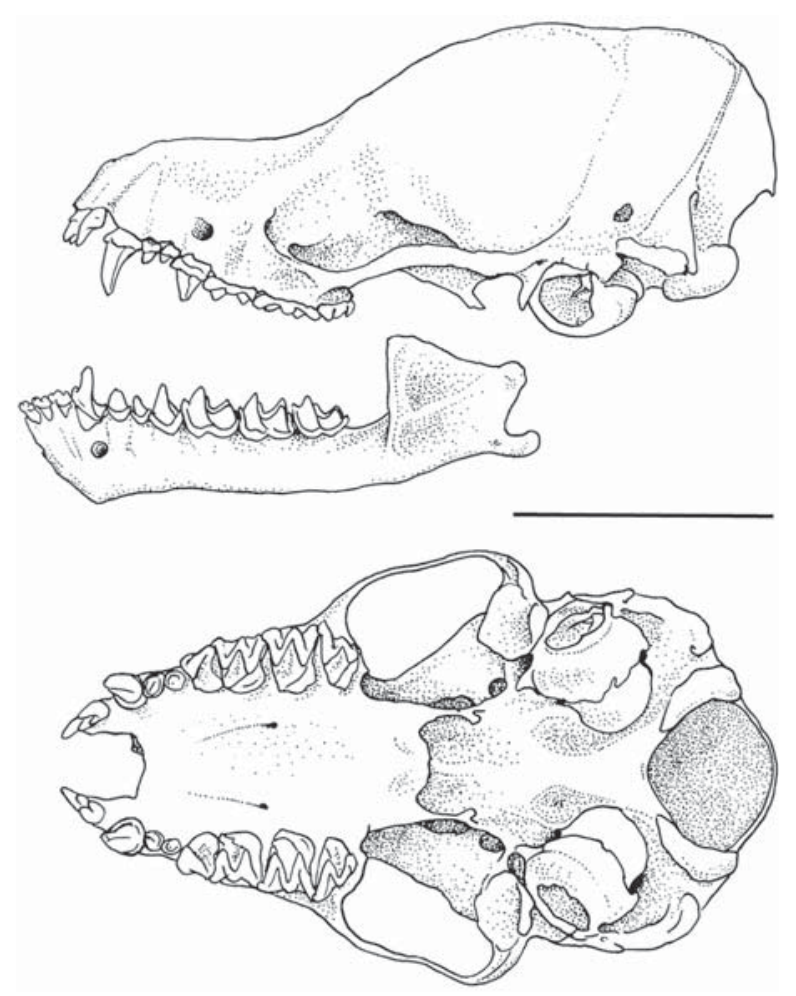

Fig. 7. Camera Lucida traced skull of the Myotis ancricola sp. n. (holotype, ZMMU S-195433). Scale bar $=5 \mathrm{~mm}$.

noid process and the mandible ramus as a whole usually proportionally higher than in $M$. annatessae.

Dentition very similar to that of $M$. annatessae. Canines proportionally smaller than in M. muricola, only slightly exceeding P4 in height. Upper canines almost round in occlusial view, with shallow but noticeable outer and inner posterior grooves. As in $M$. annatessae, inner upper incisors are about $2 / 3$ of outer incisors in crown area and slightly larger in height. Both inner and outer incisors possess additional cusps. In frontal view, both cusps of inner incisor and lingual cusp of outer incisor are on the same horizontal line. Inner lower incisors with fourth cusps, although the latter can be somewhat reduced. All upper and lower premolars are nested within tooth rows. Upper molars with rudimentary hypocones and paraconules, and with closed trigon basins. Lower molars are clearly of myotodont type, similar to most Myotis and differing from the "M. siligorensis" complex; with well-developed hypoconulids.

Baculum is ca. $0.88 \mathrm{~mm}$ in length, and $0.52 \mathrm{~mm}$ in width. It is saddle-shaped, with lateral sides convergent forward; anterior end is blunt (Fig. 6, a-b). There is no constriction in the anterior third and no downward curve of the anterior tip, which are common on penial bones of M. muricola or M. ater (Kruskop, 2013b). Border between middle part of main body and "wings" is vestigial. Compared to $M$. annatessae, baculum appears more robust and lacks a prominent basal emargination.
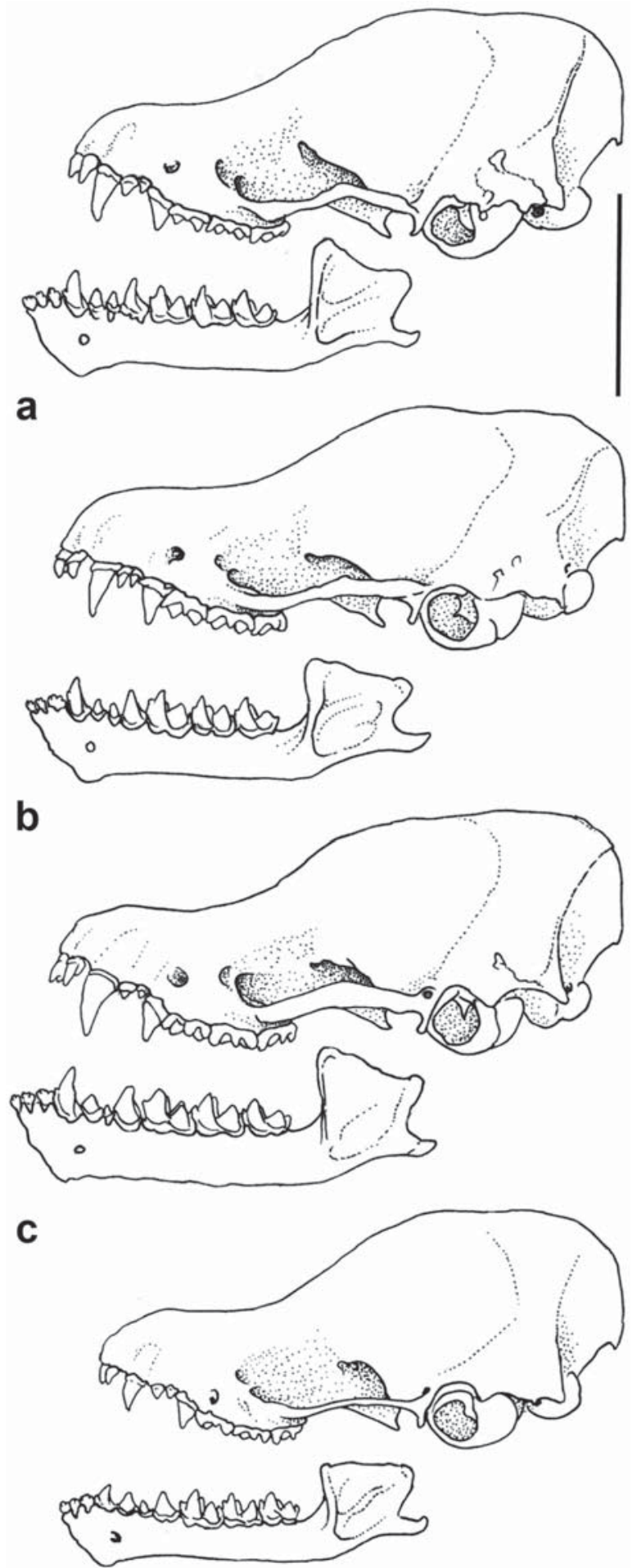

d

Fig. 8. Skull (in lateral view) of M. ancricola sp. nov. (a, ZMMU S-197023) in comparison with skulls of M. annatessae (b, ZMMU S-165043), M. muricola (c, ZMMU S195429), and M. siligorensis (d, ZMMU S-197015). Specimens ' $c$ ' and 'd' came from the M. ancricola sp. n. terra typica. Scale bar $=5 \mathrm{~mm}$. 
M. ancricola may be confused in the field with $M$. muricola and M. siligorensis. Sympatrically co-occurring specimens of $M$. muricola are larger on the average, with only small size overlap: FA ca. 33.8-38.2 (36.2) mm, BM ca. 3.9-5.8 (5.2) g; they are also usually have lighter and more brownish coloration.

Comments on natural history. All Kon Plong specimens in type series were captured at elevations of 1030-1040 m a.s.1., over small rivers and brooks, foraging at ca. 1-3 $\mathrm{m}$ above the water or bankline. Animals were seen and captured in complete darkness, between 1-6 h after sunset. In one of two observations the same habitat was used for foraging by $M$. siligorensis, although the two species were not observed there simultaneously. On the whole, the type locality is an area with a highly complex terrain forming a vast system of small gorges and narrow valleys. It is likely that the entire area was previously covered with mountain forest, but currently large parts of it are deforested. All captured bats were reproductively inactive males, therefore nothing is known about the reproductive biology of the species, or about foraging site preferences of females.

Distribution. We captured this species only in the type locality, in the eastern part of the Kon Tum Plateau (Fig. 9). Other specimens were collected in Vietnam north of Kon Tum, in Ngoc Ling mountains (Quang Nam province), and in the Attapu Province in SE Laos. It is conceivable that the distribution of $M$. ancricola $\mathrm{sp}$. n. includes mountainous territories on both sides of the Vietnamese-Laotian border between ca. $\mathrm{N} 14^{\circ}$ and $\mathrm{N} 15^{\circ}$. This area is ca. $400 \mathrm{~km}$ away from the nearest known locality of $M$. annatessae s. str.

\section{Additional remarks on taxonomy of the " $M$. annatessae" species complex}

The definition "whiskered bat morphogroup" of Benda et al. $(2012,2016)$ applied here to species complexes "muricola", "siligorensis", "annatessae" and "mystacinus" refers to the general characteristics of small-bodied (with forearm length ca. 32-40 mm) bats formerly placed within the subgenus Selysius (e.g., Tate, 1941; Findley, 1972). Although strong molecular evidence for the paraphyletic nature of this grouping has led to the abolishment of this subgenus (Ruedi \& Mayer, 2001; Stadelmann et al., 2007; Ruedi et al., $2013,2015)$, from a practical standpoint of field identification, these bats often fall into the 'everything else' category, due to size overlap and lack of prominent external diagnostic features. With the exception of the calcar keel (which varies considerably and may be completely reduced), these bats do not possess any peculiarities, such as distinctive pelage coloration, thumb pads, elongated feet or ears, shortened rostrum, etc. This has led to a somewhat arbitrary assignment of specific epithets "muricola" and "siligorensis" to specimens collected in mainland Southeast Asia and to the application of names "mystacinus" or "nipalensis" to specimens that did not clearly fall into the former two categories (see Kruskop \& Borisenko, 2013 for review).

Additional craniometric and molecular data obtained in this study corroborate earlier findings (Kruskop \& Borisenko, 2013) which suggested that $M$. annatessae represents a taxonomic lineage (or species complex) distinct from $M$. muricola. The recently collected specimen from Sin Thau, Dien Bien Province (ZMMU S193938) provides a significant range extension for $M$. annatessae. This particular point is situated about 450 $\mathrm{km}$ North-West from the nearest previously known locality of $M$. annatessae and about $800 \mathrm{~km}$ SouthWest from the nearest Chinese locality of $M$. cf. annatessae (Fig. 9). Further morphometric data on specimens from China indicate that these specimens are part of the "M. annatessae" complex, but distinct from both $M$. annatessae and M. ancricola sp. n. It is plausible that the Chinese specimens represent another taxon of a specific rank. Finally, as it was mentioned above, studied specimens from the West Bengal suggest that the possible " $M$. annatessae" complex range extends westward up to the north-east India.

The geographic distribution of collection localities of putative members of the " $M$. annatessae" species complex points to the scarcity of confirmed records (Fig. 9) but suggests a rather vast distribution area across the montane regions of southern China, mainland Southeast Asia and, possibly, also northeastern parts of the Indian Subcontinent. This area has extensive overlap with reported range of $M$. davidii/nipalensis (e.g., Smith \& Xie, 2008); therefore, given the potential for confusion among species of 'whiskered bats', such records and associated materials should be reexamined to confirm whether any of them belong to the "M. annatessae" species complex.

ACKNOWLEDGEMENTS. We would like to express our thanks to Dr. Nguyen Dung Hoi and Dr. Andrey N. Kuznetsov for administrative support and organizing of the field studies, which were carried out within the framework of the "Ecolan" program, due to the support from the Joint Vietnamese-Russian Tropical Research and Technological Centre. We are also grateful for all members of the research team for their great help in action and advice during the field work of SVK. Laboratory study of the collection materials was done in the Zoological Museum of Moscow University, using the collection facilities, with the support from its director, Dr. Mikhail V. Kalyakin. Additional collection materials were studied in Royal Ontario Museum, Canada, due to kind permission from Dr. Judith. L. Eger and Dr. Burton Lim; in the Museum of Natural History, Great Britain, under the support of Mr. Roberto Portela Miguez; in Hungarian Natural History Museum, Hungary, under the support of Dr. Gabor Csorba; and in the Zoological Institute of RAS, Russia, due to permission of Dr. Petr P. Strelkov . Molecular analyses were performed at the Centre for Biodiversity Genom- 


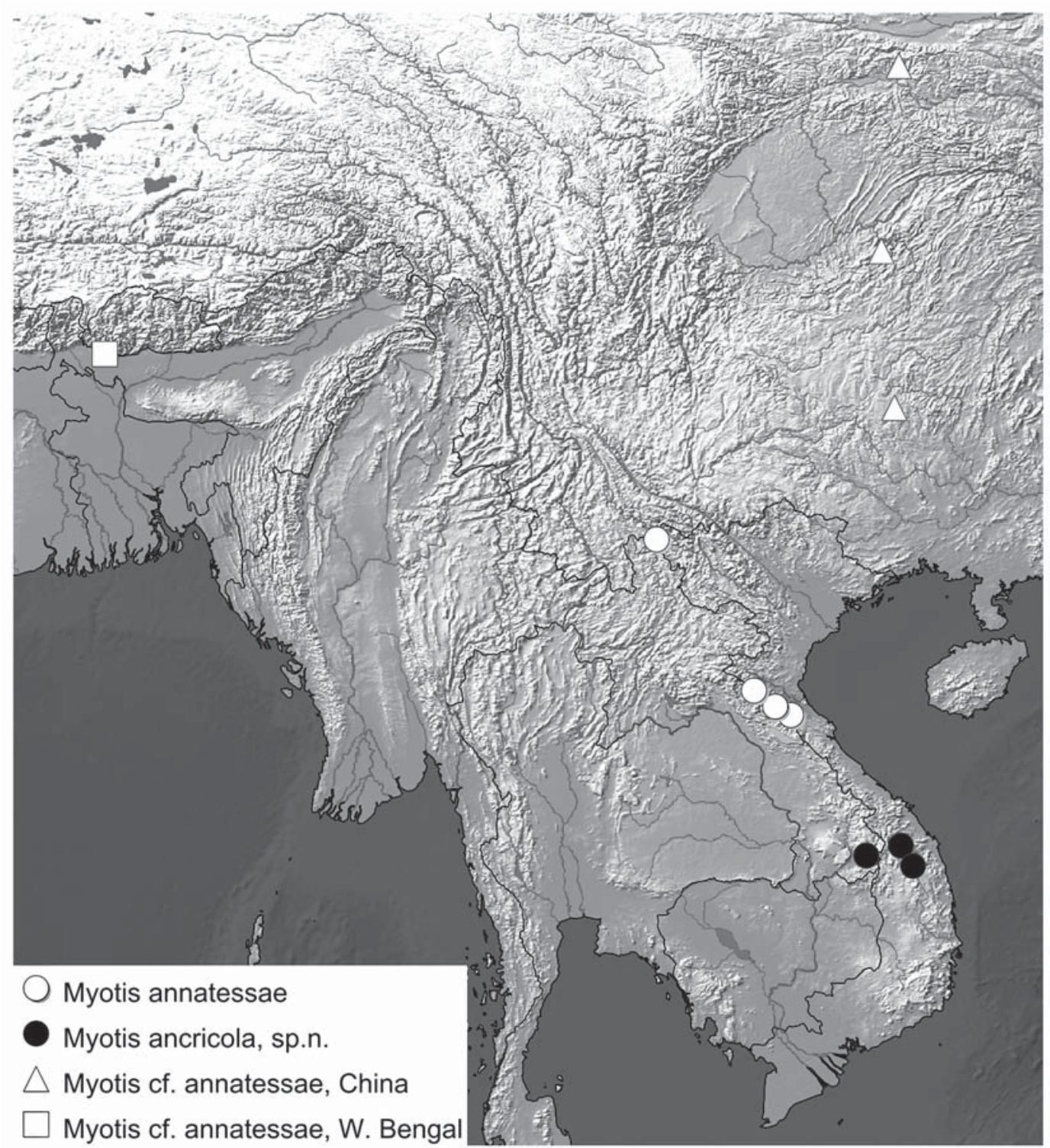

Fig. 9. Collecting localities for members of the "M. annatessae" species complex analyzed in this study. Map generated using SimpleMappr (http://www.simplemappr.net).

ics, Biodiversity Institute of Ontario, University of Guelph; we thank Dr. Muhammad Ashfaq, Mr. Norman Monkhouse and Ms. Liuqiong Liu for their help with laboratory analyses. Study of collections was supported by the Russian Foundation for Basic Research (grant No. 17-04-00689a); field survey in 2016 and final morphological analyses were carried out with support from the Russian Scientific Foundation grant No 14-5000029. The study was performed in line with State theme of scientific work of the ZMMU (AAAA-A16116021660077-3).

\section{References}

Bates B., Chambers J., Gentleman R., Hornik K., Ihaka R. et al. 2017. R: A language and environment for statistical computing. R Foundation for Statistical Computing, Vienna, Austria. https://www.R-project.org/.

Benda P. 2010. On a small collection of bats (Chiroptera) from western Sabah (North Borneo, East Malaysia) // Vespertilio. Vol.13-14. P.45-76.

Benda P., Faizolâhi K., Andreas M., Obuch J., Reiter A., Ševčík M., Uhrin M., Vallo P. \& Ashrafi S. 2012. Bats 
(Mammalia: Chiroptera) of the Eastern Mediterranean and Middle East. Part 10. Bat fauna of Iran // Acta Societatis Zoologicae Bohemicae. Vol.76. P.163-582.

Benda P., Gazaryan S. \& Vallo P. 2016. On the distribution and taxonomy of bats of the Myotis mystacinus morphogroup from the Caucasus region (Chiroptera: Vespertilionidae) // Turkish Journal of Zoology. Vol.40. P.842863.

Benda P. \& Tsytsulina K.A. 2000. Taxonomic revision of Myotis mystacinus group (Mammalia: Chiroptera) in the western Palaearctic // Acta Societas Zoologicae Bohemicae. Vol.64. P.331-398.

Borissenko A.V. 1999. Mobile trap for capturing bats // Plecotus et al. Vol.2. P.10-19. [in Russian, with English summary].

Borissenko A.V. \& Kruskop S.V. 2003. Bats of Vietnam and adjacent territories. An identification manual. Moscow: Geos. 203 p.

Csorba G., Son N.T., Saveng I. \& Furey N.M. 2011. Revealing cryptic bat diversity: three new Murina and redescription of M. tubinaris from Southeast Asia // Journal of Mammalogy. Vol.92. No.4. P.891-904.

Csorba G., Chou C., Ruedi M., Görföl T., Motokawa M., Wiantoro S., Thong V.D., Son N.T., Lin L. \& Furey N. 2014. The reds and the yellows: a review of Asian Chrysopteron Jentink, 1910 (Chiroptera: Vespertilionidae: Myotis) // Journal of Mammalogy. Vol.95. No.4. P.663-678.

Findley J.S. 1972. Phenetic relationships among bats of the genus Myotis // Systematic Zoology. Vol.21. No.1. P.3152.

Francis C.M., Borisenko A.V., Ivanova N.V., Eger J.L., Lim B.K., Guillen-Servent A., Kruskop S.V., Mackie I. \& Hebert P.D. 2010. The role of DNA barcodes in understanding and conservation of Mammal diversity in Southeast Asia // PLoS ONE. Vol.5. No.9. P.1-12.

Francis C.M. \& Eger J.L. 2012. A review of tube-nosed bats (Murina) from Laos with a description of two new species // Acta Chiropterologica. Vol.14. No.1. P.15-38.

Görföl T., Csorba G., Eger J.L., Son N.T. \& Francis C.M. 2014. Canines make the difference: a new species of Hypsugo (Chiroptera: Vespertilionidae) from Laos and Vietnam // Zootaxa. Vol.3887. No.2. P.239-250.

Hill J.E. \& Harrison D.L. 1987. The baculum in the Vespertilioninae (Chiroptera: Vespertilionidae) with a systematic review, a synopsis of Pipistrellus and Eptesicus, and the description of a new genus and subgenus // Bulletin of the British Museum of natural History (Zoology). Vol.52. No.7. P.225-305.

Horáček I. \& Hanak V. 1986. Generic status of Pipistrellus savii and comments on classification of the genus Pipistrellus (Chiroptera, Vespertilionidae) // Myotis. Vol.2324. P.9-16.

Ivanova N.V., Clare E.L. \& Borisenko A.V. 2012. DNA barcoding in Mammals // Kress W.J. \& Erickson D.L. (eds.) DNA Barcodes: Methods and Protocols. Methods in Molecular Biology. Vol.858. P.153-182.

Kruskop S.V. 2013a. Bats of Vietnam. Checklist and an identification manual. 2nd edition, revised and supplemented. Biodiversity of Vietnam series. Moscow: Mos- cow: KMK Scientific Press. 300 p.

Kruskop S.V. 2013b. The bacula of some bat species from Indo-China: the archaic plain-nosed bats (Chiroptera, Vespertilionidae: Myotinae, Kerivoulinae, Murininae) // Plecotus et al. Vol.15-16. P.3-13. [in Russian, with English summary].

Kruskop S.V. \& Borisenko A.V. 2013. A new species of South-East Asian Myotis (Chiroptera: Vespertilionidae), with comments on Vietnamese 'whiskered bats' // Acta Chiropterologica. Vol.15. No.2. P.293-305.

Kumar S., Stecher G. \& Tamura K. 2016. MEGA7: Molecular Evolutionary Genetics Analysis Version 7.0 for Bigger Datasets // Molecular Biology and Evolution. Vol.33. No.7. P.1870-1874.

Kunz T.H. \& Kurta A. 1990. Capture methods and holding devices // Kunz T.H. (ed.) Ecological and behavioral methods for the study of bats. Washington-London: Smithsonian Institution Press. P.1-29.

Kuznetsov G.V. 2006. Mammals of Vietnam. Moscow: KMK Scientific Press. 420 p. [in Russian].

Lanfear R., Calcott B., Ho S.Y.W. \& Guindon S. 2012. PartitionFinder: combined selection of partitioning schemes and substitution models for phylogenetic analyses // Molecular Biology and Evolution. Vol.29. No.6. P.1695-1701.

Ronquist F. \& Huelsenbeck J.P. 2003. MRBAYES 3: Bayesian phylogenetic inference under mixed models // Bioinformatics. Vol.19. P.1572-1574.

Ruedi M. \& Mayer F. 2001. Molecular systematics of bats of the genus Myotis (Vespertilionidae) suggests deterministic ecomorphological convergences // Molecular Phylogenetics and Evolution. Vol.21. P.436-448.

Ruedi M., Csorba G., Lin L.-K. \& Chou C.-H. 2015. Molecular phylogeny and morphological revision of Myotis bats (Chiroptera: Vespertilionidae) from Taiwan and adjacent China. // Zootaxa. Vol.3920. No.1. P.301-342.

Ruedi M., Stadelmann B., Gager Y., Douzery E.J.P., Francis C.M., Lin L.-K., Guillen-Servent A. \& Cibois A. 2013. Molecular phylogenetic reconstructions identify East Asia as the cradle for the evolution of the cosmopolitan genus Myotis (Mammalia, Chiroptera) // Molecular Phylogenetics and Evolution. Vol.69. P.437-449.

Sikes R.S., Bryan II J.A., Byman D., Danielson B.J., Eggleston J. et al. 2016. 2016 Guidelines of the American Society of Mammalogists for the use of wild mammals in research and education // Journal of Mammalogy. Vol.97. No.3. P.663-688.

Simmons N.B. 2005. Order Chiroptera // Wilson D.E. \& Reeder D.M. (eds.) Wilson D.E. \& Reeder D.M. (eds.). Mammal Species of the World. Baltimore: Johns Hopkins University Press. Vol.1. P.312-529.

Smith A.T. \& Xie Y. 2008. A guide to the Mammals of China. Princeton: Princeton University Press. 544 p.

Son N.T., Csorba G., Tu V.T., Thong V.D., Wu Y., Harada M., Oshida T., Endo H. \& Motokawa M. 2015. A new species of the genus Murina (Chiroptera: Vespertilionidae) from the Central Highlands of Vietnam with a review of the subfamily Murininae in Vietnam // Acta Chiropterologica. Vol.17. No.2. P.201-232.

Stadelmann B., Lin L.-K., Kunz T.H. \& Ruedi M. 2007. Molecular phylogeny of New World Myotis (Chiroptera, 
Vespertilionidae) inferred from mitochondrial and nuclear DNA genes // Molecular Phylogenetics and Evolution. Vol.43. P.32-48.

Strelkov P.P. 1989. New data on the structure of baculum in Palaearctic bats. I. The genera Myotis, Plecotus, and Barbastella // Hanak V., Horáèek I. \& Gaisler J. (eds.) European bat research 1987. Praha: Charles University Press. P.87-94.

Tamura K., Dudley J., Nei M. \& Kumar S. 2007. MEGA4: Molecular Evolutionary Genetics Analysis (MEGA) Software Version 4.0 // Molecular Biology and Evolution. Vol.24. P.1596-1599.

Tamura K., Peterson D., Peterson N., Stecher G., Nei M. \& Kumar S. 2011. MEGA5: Molecular Evolutionary Genetics Analysis Using Maximum Likelihood, Evolutionary Distance, and Maximum Parsimony Methods // Molecular Biology and Evolution. Vol.28. P.2731-2739.
Tate G.H.H. 1941. A review of the genus Myotis (Chiroptera) of Eurasia, with special reference to species occurring in the East Indies // Bulletin of the American Museum of Natural History. Vol.78. P.537-565.

Thong V.D., Puechmaille S.J., Denzinger A., Dietz C., Csorba G., Bates P., Teeling E.C. \& Schnitzler H.-U. 2012. A new species of Hipposideros (Chiroptera: Hipposideridae) from Vietnam // Journal of Mammalogy. Vol.93. No.1. P.1-11.

Tu V.T., Csorba G., Görföl T., Arai S., Son N.T., Thanh H.T. \& Hasanin A. 2015. Description of a new species of the genus Aselliscus (Chiroptera, Hipposideridae) from Vietnam // Acta Chiropterologica. Vol.17. No.2. P.233-254.

Warren D.L., Geneva A.J. \& Lanfear R. 2017. RWTY (R We There Yet): An R package for examining convergence of Bayesian phylogenetic analyses // Molecular Biology and Evolution. Vol.34. No.4. P.1016-1020.

Appendix 1. List of Myotis specimens, used for morphometric analyses. Information is in the following order: species name, geographic region, museum acronyms, specimen numbers, sex in parentheses. Institutional abbreviations see in Materials and methods

M. muricola. India: HNHM 92.106.1. (female); Nepal: HNHM 98.5.24. (female), BMNH 45.1.8.143 (female, type of M. muricola), BMNH 45.1.8.417 (female), ZMMU S-164491 (male); Myanmar: ZMB 3400 (male, type of M. lobipes); China, Guangxi: ROM 116134, ROM 116423 (females); China, Hunan: ROM 115058 (female); N. Vietnam: MNHN 1983-1923 (female), ZMB 54034 (sex unknown); C. Vietnam: ZMMU S-165048 (female), ZMMU S-165055, ZMMU S-195429, ZMMU S-195431 (male), BMNH 26.10.4.22 (male), ZMB 62613 (sex unknown); S. Vietnam: ZMMU S-172611, ZMMU S-172615, ZMMU S-172620, ZMMU S-172623, ZMMU S172624, ZMMU S-172629, ZMMU S-172631, ZMMU S-173410, ZMMU S-184680, ZMMU S-186603, ZMMU S-188173 (females), ZMMU S-172619, ZMMU S-172626, ZMMU S-172630, ZMMU S-188181 (males), ZIN 5930 (male), MNHN 1911-596 (sex unknown); Laos: MNHN 2006-0080 (female), ROM 106388 (female), ROM 110606 (male); Cambodia: ZCU 09, ZCU 10 (females), ZCU 11, ZCU 12 (males); Thailand: ZCU 03 (male); Malaysia: ROM 38001, ROM 38002, ROM 38183, ROM 38194 (females), ROM 38182, ROM 40008, ROM 40009, ROM 40943 (males), ZMB 4099 (sex unknown); MNHN 1975-544.6 (female), MNHN 1975-544.1, MNHN 1975-544.2, MNHN 1975-544.3, MNHN 1975-544.7 (males), MNHN 1975-544.8 (sex unknown), MNHN 1983-1886, MNHN 1983-1887, MNHN 1983-1892, MNHN 1983-1893, MNHN 1983-1894 (females), MNHN 1983-1895, MNHN 1983-1898, MNHN 1983-1910 (males); Borneo: NMW 28517 (sex unknown), ZMB 48335 (male), ZMB48336 (female), HNHM 2869/23.1, HNHM 2869/23.2 (males), MNHN 1959-219, MNHN 1975-544 (sex unknown); The Philippines: ZMB 54167 (male); Java: MNHN 1983-1476 (female), NMW 28392 (female), ZMMU S-103262, ZMMU S-103265, ZMMU S-103269 (females), NMW 28366 (male), ZMMU S103266, ZMMU S-103268 (males), MNHN 1911-1402, ZMB 67004, ZMB 67005, ZMB 67006 (sex unknown); Sumatra: NMW 39404, NMW 39405, NMW 39406, NMW 39408, NMW 39409, NMW 39410, NMW 39416, NMW 39417, NMW 39427, NMW 39428, NMW 39430, NMW 39437, NMW 39450 (females), NMW 39398, NMW 39399, NMW 39400, NMW 39401, NMW 39412, NMW 39424, NMW 39425, NMW 39426 (males), HNHM 2869/3 (male), ZIN 84715, ZIN 84717, ZIN 84718, ZIN 84719 (males), MNHN 1895-447, MNHN 190695 (sex unknown); Sumba Is.: NMW 28515, NMW 28516 (females), NMW 28514 (male), ZMB 54615, ZMB 92153, ZMB 92155 (females), ZMB 92154, ZMB 92157 (males), ZMB 92152 (sex unknown).

M. cf. muricola. Borneo: ROM 117948 (male); Borneo, Sabah (originally identified as M. cf. nugax ): ROM 117947 (female), ROM 117943, ROM 117944 (males); The Moluccas: ZMB 66984; ZMB 66986, ZMB 66987 (sex unknown); Sulawesi (originally identified as M. browni): BMNH 82.120, BMNH 82.121, BMNH 82.123 (females), BMNH 82.122 (male); ZMB 66991 (sex unknown).

M. davidii. China: BMNH 9.1.1.1 (male), MNHN 1987-296 (male, type of M. davidii), MNHN 1911-739 (female), ROM 112957, ROM 112958, ROM 112959 (females); N-W. India: BMNH 10.1.18.1 (sex unknown), BMNH 26.3.1.1 (female, type of M. meinertzhageni), BMNH 71.13 (female); Uzbekistan: ZMMU S-6819, ZMMU S-94702 (female), ZMMU S-29225, ZMMU S-94703 (sex unknown); Turkmenistan: ZMMU S-29214 (male), ZMMU S-104449, ZMMU S-104448 (females), ZMMU S-29222 (sex unknown). 
M. annatessae. C. Vietnam: ZMMU S-164986, ZMMU S-164988, ZMMU S-165046, ZMMU S-165047 (females), ZMMU S-164987, ZMMU S-164989, ZMMU S-165042, ZMMU S-165043, ZMMU S-165044 (males); Laos: ROM 106476 (female).

M. cf. annatessae. China, Shaanxi: NMP 90553 (sex unknown); China, Guizhou: ROM 117808 ROM 117809 (males), ROM 118578, ROM 118580, ROM 118581, ROM 118584, ROM 118616, ROM 118653; India, West Bengal: BMNH 16.7.29.39, BMNH 16.7.29.40, BMNH 16.7.29.41 (females), BMNH 16.7.29.38, BMNH 16.7.29.90, BMNH 16.9.29.37 (males).

M. ancricola sp.n. C. Vietnam: ROM 111270 (female), ROM 111271 (male), ZMMU S-195433, ZMMU S195434, ZMMU S-197021, ZMMU S-197023 (males); Laos: ROM 110487, ROM 110536, ROM 110551, ROM 110553, ROM 110557 (females), ROM 110537 (male).

Appendix 2. List of the BOLD Process ID numbers for specimens used in the analysis. 06 ;

Myotis annamiticus: BM586-04, SKBPA022-06, SKBPA023-06, SKBPA025-06, SKBPA078-06, SKBPA079-

Myotis annatessae s. str.: ABBM488-07, BM016-03, BM213-03;

Myotis cf. annatessae: ABBM129-05, ABBM142-05, ABCMA089-06, ABCMA760-07, ABCMA798-07, ABCMA801-07, ABCMA833-07, ABCMA834-07, ABCMA870-07, ABRVN467-06, BM361-04; Myotis annectens: SKMZM1127-12, SKMZM1139-12;

Myotis ater: ABBSI193-10, ABBSI196-10, ABBSI198-10, ABBSI208-10, ABBSI230-10, ABBSI232-10, ABBSI237-10, ABBSI239-10, ABBSI250-10, ABBSI367-11, ABBSI368-11, ABBSI369-11, ABBSI391-11, ABBSI392-11, ABBSI393-11, ABBSI408-11, ABBSI409-11, BM635-04, SKMZM1116-12; Myotis davidii: ABCMA291-06, ABCMA292-06, ABCMA293-06, SKBPA154-07; Myotis (brandtii) sibiricus: SKBPA132-07, SKBPA133-07, SKBPA146-07, SKBPA147-07, SKBPA148-07, SKBPA182-07, SKBPA292-07, SKBPA293-07, SKBPA294-07, SKBPA295-07, SKBPA296-07; Myotis ikonnikovi: SKBPA099-07, SKBPA101-07, SKBPA102-07, SKBPA103-07, SKBPA145-07, SKBPA238-07, SKBPA549-08; Myotis montivagus: ABBSI287-11, ABBSI288-11, ABBSI289-11, ABBSI290-11, ABBSI291-11, ABBSI292-11, SKMZM1235-13, SKMZM1238-13, SKMZM954-10; Myotis muricola: ABBSI148-09, ABBSI156-09, ABBSI162-09, ABBSI181-09, ABBSI199-10, ABBSI20110, ABBSI214-10, ABBSI227-10, ABBSI231-10, ABBSI233-10, ABBSI238-10, ABBSI242-10, ABBSI243-10, ABBSI351-11, ABBSI352-11, ABBSI353-11, ABBSI354-11, ABBSI370-11, ABBSI377-11, ABRVN309-06, BM613-04, SKBPA503-08, SKMZM1142-12, SKMZM1166-13, SKMZM1168-13, SKMZM1169-13, SKMZM1178-13, SKMZM1195-13, SKMZM1200-13, SKMZM1201-13, SKMZM1215-13, SKMZM1216-13, SKMZM1218-13, SKZMR012-16, SKZMR013-16, SKZMR074-16; Myotis cf. muricola: ABCMA511-06, BM601-04, SKZMR040-16, SKZMR062-16, SKZMR063-16, SKZMR067-16; Myotis phanluongi: BM625-04, SKBPA020-06, SKBPA032-06, SKBPA507-08, SKMZM1204-13, SKZMR089-16, SKZMR094-16; Myotis rosseti: ABBSI257-10, ABBSI394-11, ABBSI395-11; Myotis siligorensis: ABBSI293-11, ABBSI294-11, SKBPA021-06, SKBPA026-06, SKBPA029-06, SKMZM1082-12, SKMZM1086-12, SKMZM1089-12, SKMZM1092-12, SKMZM1096-12, SKZMR036-16, SKZMR044-16, SKZMR066-16, SKZMR073-16, SKZMR075-16, SKZMR082-16; Myotis ancricola sp. n.: SKZMR015-16, SKZMR017-16, SKZMR068-16. 